Article

\title{
Investigating Combustion Process of N-Butanol-Diesel Blends in a Diesel Engine with Variable Compression Ratio
}

\author{
György Szabados ${ }^{1, *}$, Kristóf Lukács ${ }^{2}$ and Ákos Bereczky ${ }^{2}$ \\ 1 Doctoral School of Multidisciplinary Sciences, Széchenyi István University, Egyetem tér 1, \\ 9026 Győr, Hungary \\ 2 Department of Energy Engineering, Budapest University of Technology and Economics, Múegyetem rkp. 3, \\ 1111 Budapest, Hungary; lukacs@energia.bme.hu (K.L.); bereczky@energia.bme.hu (Á.B.) \\ * Correspondence: szabados.gyorgy.gergo@ga.sze.hu or szabados.giorgio@gmail.com
}

check for updates

Citation: Szabados, G.; Lukács, K.; Bereczky, Á. Investigating

Combustion Process of

N-Butanol-Diesel Blends in a Diesel Engine with Variable Compression Ratio. Clean Technol. 2021, 3, 618-628. https://doi.org/10.3390/ cleantechnol3030037

Academic Editors: Patricia Luis,

Stanislaw Szwaja and

Romualdas Juknelevičius

Received: 20 March 2021

Accepted: 13 August 2021

Published: 20 August 2021

Publisher's Note: MDPI stays neutral with regard to jurisdictional claims in published maps and institutional affiliations.

Copyright: (c) 2021 by the authors. Licensee MDPI, Basel, Switzerland. This article is an open access article distributed under the terms and conditions of the Creative Commons Attribution (CC BY) license (https:// creativecommons.org/licenses/by/ $4.0 /)$.

\begin{abstract}
The search for alternative fuels for internal combustion engines is ongoing. Among the alternatives, plant-based fuels can also be mentioned. Alcohol is not a common fuel for diesel engines because the physical and chemical properties of the alcohols are closer to those of gasoline. In our research, the combustion properties of diesel-n-butanol mixtures have been investigated to obtain results on the effect of butanol blending on combustion. Among the combustion properties, ignition delay, in-cylinder pressure, and heat release rate can be mentioned. They have been observed under different compression conditions on an engine on which the compression ratio can be adjusted. The method used was a quite simple one, so the speed of the engine was set to a constant 900 rpm without load, while three compression ratios $(19.92,15.27$, and 12.53) were adjusted with a fuel flow rate of $13 \mathrm{~mL} / \mathrm{min}$ and the pre-injection angle of $18^{\circ}$ BTDC. Blending butanol into the investigated fuel does not significantly affect maximal values of indicated pressure, while much more effect on the pressure rising rate can be detected. Furthermore, heat release rate and ignition delay increased at every compression ratio investigated. Despite the low blending rates of butanol in the mixtures, butanol significantly affects the combustion parameters, especially at high compression ratios.
\end{abstract}

Keywords: n-butanol-diesel blends; combustion analyses; heat release rate; ignition delay; diesel engine

\section{Introduction}

The energy carriers consumed in all the sectors are transformed into harmful pollutants that make the air around us more and more polluted. If we focus on transport as one of the most important sectors, forecasting studies [1-4] calculate a rising energy demand in this sector, which is related to the nearer and the distant future in a global perspective. Besides conventional energy or fuel in the sector, bio-derived sources are predicted to grow until by 2050. The extent to which it changes mainly depends on the region and energy source, but an average may be $28 \%$ in growth compared to the value in 2020 in Western Europe [5,6]. For the share of biofuels, each study predicts otherwise. According to [4], this share will reach quite a high level, ca. 30\%. Results of [7] show us a slightly lower value, which is $25 \%$ on average related to Europe. In comparison, a worldwide calculation [2] forecasts a quite small share of $5 \%$ compared to the previous ones regarding the share of renewable energy in transportation. Many alternative and renewable energy sources have been studied, investigated instead as complementary rather than a substitute to conventional sources in this sector. The aim of the utilization of biofuels is primarily the diversification of fuel resources: (i) preservation of fossil stocks, (ii) decreasing the GHG emissions, and (iii) keeping energy security $[8,9]$. Requirements regarding the utilization rate of renewable energy in all the sectors in the European Union are set out in a regulation, which is a compulsory target for every member state of the Union [10]. This utilization rate differs from country to country. For example, in Hungary, this value was planned, for a not so high estimate, approximately $14 \%$, while, e.g., in a country out of the Union, the 
share of renewable energy compared to the total energy consumption of Brazil reaches $42 \%$, making this country a world leader from this point of view [11]; but, wood-burning heating is dominant in Brazil.

This paper deals with the use of higher alcohol, n-butanol, in compression ignition engines. n-butanol can be a special renewable fuel blended with diesel. In the next section, we will review the main parameters of pre-combustion and combustion processes in a compression-ignition internal combustion engine, which are in chronological order: injection, atomization, evaporation, ignition, premixed, and diffuse combustion; they are decisive for the engine output parameters and specify how certain fuels or mixtures may be used in an engine. Butanol, in terms of physical and chemical parameters, is a fuel closer to gasoline; however, several studies have already examined its use in diesel engines [12-15].

Liu et al. [16] injected triple mixtures (soybean oil methyl ester-diesel-n-butanol) in different compositions into a constant volume combustion chamber. The mixing ratios were set so that the surface tension was close to: BU5S15D80, BU10S10D80, and BU0S20D80 fuel mixture was used as a reference. Examination of the combustion process revealed that very intense premixed combustion was observed at initial temperatures of $800 \mathrm{~K}$ and $900 \mathrm{~K}$. However, at an initial temperature of $1200 \mathrm{~K}$, only "controlled combustion" was observed, i.e., no premixed and diffuse combustion separated. By decreasing the initial temperature, the maximum values of heat release decreased. Based on the test results, it was found that the incorporation of n-butanol promoted premixed combustion. For $5 \mathrm{~V} / \mathrm{V} \%$ and $10 \mathrm{~V} / \mathrm{V} \%$ n-butanol mixtures, a lower n-butanol ratio at an initial temperature of $800 \mathrm{~K}$ results in a lower peak combustion pressure. The maximum combustion chamber pressure for the $10 \mathrm{~V} / \mathrm{V} \%$ n-butanol mixture is about $10 \%$ higher than for the $5 \% \mathrm{~V} / \mathrm{V}$ n-butanol.

Experiments were performed by Lapuerta et al. [17] in a constant volume experimental apparatus (Herzog Cetane ID510) at different pressures and temperatures, including diesel and n-butanol and mixtures of diesel and ethanol, 0-100 V/V\% for n-butanol and 0-75 V/V\% for ethanol. The reference pressure was $21 \mathrm{bar}$, and the temperature was $875 \mathrm{~K}$. Based on the measurements, it was observed that the inflammation time of both cold burning and main burning increased due to the two alcohol mixtures, approx. up to $50 \mathrm{~V} / \mathrm{V} \%$ mixing ratio in proportion to mixing, which was explained by the decreasing cetane number. The effect of pressure change was studied. By reducing the pressure from 21 bars to 16 bars, the ignition delay increased significantly, while this effect was no longer significant by increasing the pressure from 16 bars, the ignition delay changed slightly. As the temperature increased, the ignition time decreased significantly, but it was found that at temperatures above $913 \mathrm{~K}$, the rate of decrease was no longer significant. Another important finding of the research is that increasing the alcohol content decreased the maximum pressure. This was justified by the authors for three reasons: the amount of heat input decreases due to the decrease in calorific value, the mixture became poorer due to the lower theoretical combustion air demand, and due to the increased ignition time, the mixture became more and more distributed in the combustion chamber. However, it was found that in the case of the 5-20 V/V\% n-butanol mixing ratios, the pressure maximum increased, but only for $n$-butanol mixtures. This was justified by the increased burning rate.

The experiments performed by Liu et al. are important in connection with the increased burning rate [18]. The authors also performed measurements at different pressures and temperatures $(800 \mathrm{~K}, 900 \mathrm{~K}, 1000 \mathrm{~K}$, and $1200 \mathrm{~K})$ in a constant volume system. In this article, two fuel mixtures including two kinds of alcohol have been investigated that were BU20S80 and E20S80. The time course of the injection was investigated, during which it was determined from the high-speed camera recordings that the peak of the fuel jet disintegrated during the injection at $800 \mathrm{~K}$ and $900 \mathrm{~K}$. This has been explained by significantly different evaporation properties of biodiesel and alcohols, as butanol and ethanol have much lower boiling points compared to biodiesel. It is assumed that moving radially during heating, the alcohol content will partially reach the superhot temperature, and this will lead to the formation of bubbles, which will result in a "steam explosion". They found that this phenomenon did not occur at higher temperatures, as there is no time to do so 
due to faster evaporation and earlier ignition. Furthermore, based on the pressure change measured in the constant volume combustion chamber and the useful heat release rate (HRR) calculated from it, the authors examined the evolution of the combustion process and the ignition time. They found that the system is not considered adiabatic, with a significant effect on heat transfer between the flame wall. Based on their measurement results, E20S80 fuel resulted in higher peak pressure compared to BU20S80 fuel, which is a consequence of the better heat release property of the E20S80 fuel. A possible explanation for this observation is that with E20S80, the combustion occurred farther from the wall, resulting in lower heat loss. Furthermore, the higher heat of evaporation of ethanol results in a lower flame temperature, which led to lower heat loss; moreover, the higher laminar flame spread rate of ethanol has a significant effect on the ethanol combustion process; thus, overall, the ethanol mixture burned faster.

Few data can be found on the flame propagation rate of diesel-alcohol mixtures, only one such literature has been found in our literature search [19]. Chaichan performed tests in a cylindrical, constant volume container, igniting various mixtures in the cylinder using electrodes, then determined the flame propagation rate based on the results of thermocouples [20]. Its measurements examined Iraqi diesel (D2), B20, M20, and E20. To ensure the stability of the methanol mixture, $2 \mathrm{~V} / \mathrm{V} \%$ iso-butanol and a cetane number enhancer $(2 \mathrm{~V} / \mathrm{V} \%)$ were used. For the same purpose, $1.5 \mathrm{~V} / \mathrm{V} \%$ solvent and cetane number booster were used for ethanol. Based on the measurement results, it can be stated that the flame spread rate increased slightly $(<10 \%)$ as a result of methanol mixing; while ethanol blending decreased slightly $(<10 \%)$, biodiesel had the largest decrease $(<15 \%)$.

Veloo et al. performed measurements with all three alcohols at atmospheric pressure using the twin flame method (counter flow) [21]. Based on their results, it can be concluded that $\mathrm{n}$-butanol has the highest flame spread rate in the case of a fuel-poor mixture, but this is close to the flame spread rate of ethanol and that of methanol is the lowest. In the stoichiometric case, the flame spread of ethanol and n-butanol is nearly the same, while that of methanol is slightly higher. In the case of fuel-rich mixtures, methanol has the highest flame spread rate, and n-butanol has the lowest.

Glaude et al. have published a publication on the adiabatic flame temperature of the fuels under study [22], including biodiesels (FAME) and fossil fuels produced from different feed stocks supplemented with one-component renewable fuels such as alcohols. Based on the results, it can be stated that the adiabatic flame temperature of the studied alcohols (approx. $2200 \mathrm{~K}$ in the case of methanol, approx. $2260 \mathrm{~K}$ in the case of butanol) is lower than the adiabatic flame temperatures of gas oils and biodiesel. It is important to note that the effect of the heat of evaporation is not included in the results.

Similar trends are shown by Davis and Law [23] for the adiabatic flame temperature of methanol and ethanol. According to the authors, although n-heptane is a widely used molecule for diesel modelling, its chemical and physical properties are far removed from a true diesel fuel (D2).

Based on calculation regarding theoretical oxygen (air) demand and $\mathrm{CO}_{2}$ emission and intensity of fuels such as diesel, butanol and their blends, methodology, and data are taken from [24-30]. The conclusion is that at a butanol blending ratio of $20 \%$ to diesel, the air demand for n-butanol decreased significantly by $27 \%$. This assumes an improvement in combustion quality, assuming a similar mixing, so that $\mathrm{CO}, \mathrm{THC}$, and $\mathrm{PM}$ emissions, which are characteristic of worse combustion processes, are expected to decrease only when this effect is taken into account. Additionally, taking into account GHG emissions, $\mathrm{CO}_{2}$ emissions per mass of fuel are also reduced by $26 \%$, which is a significant achievement, especially considering that $\mathrm{n}$-butanol can also be produced from renewable raw materials [31,32], leading to an additional reduction in $\mathrm{CO}_{2}$ emission. On the other hand, when looking at $\mathrm{CO}_{2}$ emissions per calorific value, the reduction is only $4 \%$ due to the significantly lower calorific value of n-butanol. However, it has several additional benefits $[33,34]$, for example: it has no sulfur content—unlike traditional fossil fuel fuels: 
- $\quad \mathrm{n}$-butanol has a lower auto-ignition temperature than methanol and ethanol, making it easier to ignite in diesel engines;

- $\quad \mathrm{n}$-butanol has better evaporation properties, higher cetane number, and energy density than ethanol and methanol;

- $\mathrm{n}$-butanol is able to clean the fuel system, including the injector, and has better mixing properties.

Based on all of these above, it is worth examining the combustion properties of diesel and n-butanol blends.

Based on a review of the literature introduced above, the following can be summarized regarding the combustion properties of n-butanol:

During the evaporation of the diesel-n-butanol mixture, n-butanol starts to evaporate sooner and more intensively; thus, a significant amount evaporates and can largely form a combustible mixture. However, due to the higher auto-ignition temperature of n-butanol than diesel, the combustion process will only be initiated by the ignition of diesel. As a result, the burning intensity of the premixed section increases. Therefore, the pressure increase is greater, and the combustion of the premixed section is more intense, resulting in increasing average and local temperatures.

Butanol production efficiency and economics can make the use of butanol fuel blends attractive. With such a perspective, a more complex evaluation can be done about an alternative fuel, but this was not the aim of this study and measurement series, which narrowly focuses on the combustion properties of diesel's alternative fuel in reciprocating the piston engine.

\section{Experimental}

\subsection{Engine and Method}

To verify the hypothesis above, several series of measurements have been carried out with an engine that had various values of compression ratio. The engine measurements were performed on a CFR cetane rating engine; this is a single cylinder, four-stroke cycle pre-chamber type diesel engine. The displacement volume is $610 \mathrm{~cm}^{3}$ and the speed is $900 \mathrm{rpm}$, which is the value determined by the ASTM standard. At an opening pressure of 120 bar, the injector injects fuel primarily onto the wall of the compression piston and the wall of the pre-chamber. Measurements were made for three compression ratios (19.92, 15.27 , and 12.53), fuel consumption was set at $13 \mathrm{~mL} / \mathrm{min}$, and the pre-injection angle was set to $18^{\circ}$ BTDC for better handling.

An indication system has been installed on the engine to measure and records the in-cylinder pressure parameter as a function of the crankshaft rotation angle. The pressure data were displayed and evaluated, and the heat release from the pressure data was also calculated using a computer program.

The engine used in the research is really a specific one. It has specific characteristic from many points of view. Diesel engines built in vehicles today have a whole different design regarding fuel supply system, mixture formation combustion, and combustion chamber, etc. The parameters investigated in this study depend highly on the engine's construction especially concerning the combustion process. Thus, in the authors' opinion, further investigations would be needed with the same fuel blends on different engines (with different compression ratio) to improve the degree of universality of these results or data.

A detailed chemical kinetic analysis of the combustion process would also be very meaningful and useful. It can be a next step in the research. The aim of this research was to investigate the "global" parameters of the combustion process. Global parameters would be, in this case, in-cylinder pressure, heat release rate, ignition delay, etc. Additionally, global combustion-related parameters would also be $\mathrm{O}_{2}$ consumption and $\mathrm{CO}_{2}$ emission, which are also combustion-related parameters. 


\subsection{Investigated Fuel Blends}

The measurement series had a focus on four different fuels; from those, three are a blend of diesel and butanol with three different mixing ratios. So, basic fuel was the diesel the original fuel of these engines. Three different fuel blends have been made on a volumetric basis with blending butanol to the original one $(5 \mathrm{~V} / \mathrm{V} \%, 10 \mathrm{~V} / \mathrm{V} \%$, and $20 \mathrm{~V} / \mathrm{V} \%$ of butanol to diesel).

Some ICE-relevant parameters, which are probably the most important ones regarding a combustion process in an engine, are listed in Table 1 . These are the properties of pure diesel and n-butanol. Based on the values in the table, the addition of butanol to diesel changes the parameters in the following direction relative to the value of diesel:

- Lower heating value, cetane number decrease, and kinematic viscosity increase. All these are negative factors regarding combustion efficiency.

- Density and boiling point drop, which is a good direction but increasing self-ignition temperature and heat of evaporation of butanol also takes the blend in a negative direction.

Table 1. ICE-relevant fuel properties $[35,36]$.

\begin{tabular}{cccc}
\hline Property & Measurement Unit & D2 & N-Butanol \\
\hline LHV & $\mathrm{MJ} / \mathrm{kg}$ & 43 & 33.1 \\
Cetane number & - & 51 & 25 \\
Kinematic viscosity $\left(\right.$ at $\left.40{ }^{\circ} \mathrm{C}\right)$ & $\mathrm{mm}^{2} / \mathrm{s}$ & 3.4 & 3.6 \\
Density $\left(\right.$ at $\left.20^{\circ} \mathrm{C}\right)$ & $\mathrm{kg} / \mathrm{m}^{3}$ & 837 & 810 \\
Boiling point & $\mathrm{K}$ & $453-643$ & 390 \\
Temperature of self-ignition & $\mathrm{K}$ & 503 & 618 \\
Heat of evaporation & $\mathrm{KJ} / \mathrm{kg}$ & 250 & 585 \\
\hline
\end{tabular}

The function of the parameter changes is different and due to the small mixing ratios, it is certainly only small.

\section{Results and Discussion}

To investigate the butanol's effect on the combustion process, it is useful to use the in-cylinder pressure and temperature curves. As these two parameters can only partially be separated from each other under engine investigation circumstances, therefore, a cetane rating unit was used to conduct measurements. This engine has two significant characteristics. On the one hand, it has a pre-chamber diesel engine, and on the other hand, the engine's compression ratio can be changed by changing the volume of the pre-chamber. The recorded in-cylinder pressure curves and the calculated HRR can be seen in Figure 1. Another interesting phenomenon can be observed in this figure, so before the ignition, there is a local maximum in the heat release rate curve, this might be a consequence of a cold combustion process. For a compression ratio of 19.92, the pressure maxima of D2 and BU5 and BU10 deviate relatively from the pressure maxima of BU20 by $2.1 \%, 3.2 \%$, and $2.1 \%$, respectively. These values are less than the measurement uncertainty of $3.59 \%$. This tendency is even more pronounced in the case of the other two compression ratios.

The oscillation of pressure and heat release curves is well observable, which might be a result of the different spots of the pre-chamber and the pressure sensor installed. With increasing the compression ratios, the pressure's maximums will be higher, while the situation of increasing the alcohol content in the fuel blend investigated does not have a significant effect on the maximal values of in-cylinder pressure. The situation can be followed in Figure 2. However, in the case of 19.92 of the compression ratio, the peak pressure has increased at $20 \mathrm{~V} / \mathrm{V} \%$ butanol in the blend. It is important to form the point of view that the fuel consumption was constant, so the heat performance introduced into the engine was lower with increased alcohol content in the blend. However, the extent of reduction is not a significant one. Based on the values showed in Table 1, the volumetric-specified lower heating values $\left(\mathrm{MJ} / \mathrm{m}^{3}\right)$ show a relative difference of $1.3 \%$, 
$2.6 \%$, and $5.1 \%$ accordingly to blends of BU5, BU10, and BU20 compared to that of diesel. Pressure changing rate $\left(\mathrm{dp}_{\mathrm{in}-\mathrm{Cyl}} / \mathrm{d} \varphi\right.$ max. $)$ resulted in a tendency that is inverse with the compression ratio when D2 has been investigated. The reason is probably that the period of ignition delay was decreasing with increasing compression ratio. In this case, a fuel mix with butanol pressure changing rate showed, firstly, a rising tendency but continued dropping when the compression ratio was set to 12.53 and the blending rate of butanol arose in the mix. With the compression value of 15.27 and with increasing bio blending rate, the observed tendency seemed to be a rising one. As for the set of compression ratio 19.92 , the investigated pressure rate showed a constant value.

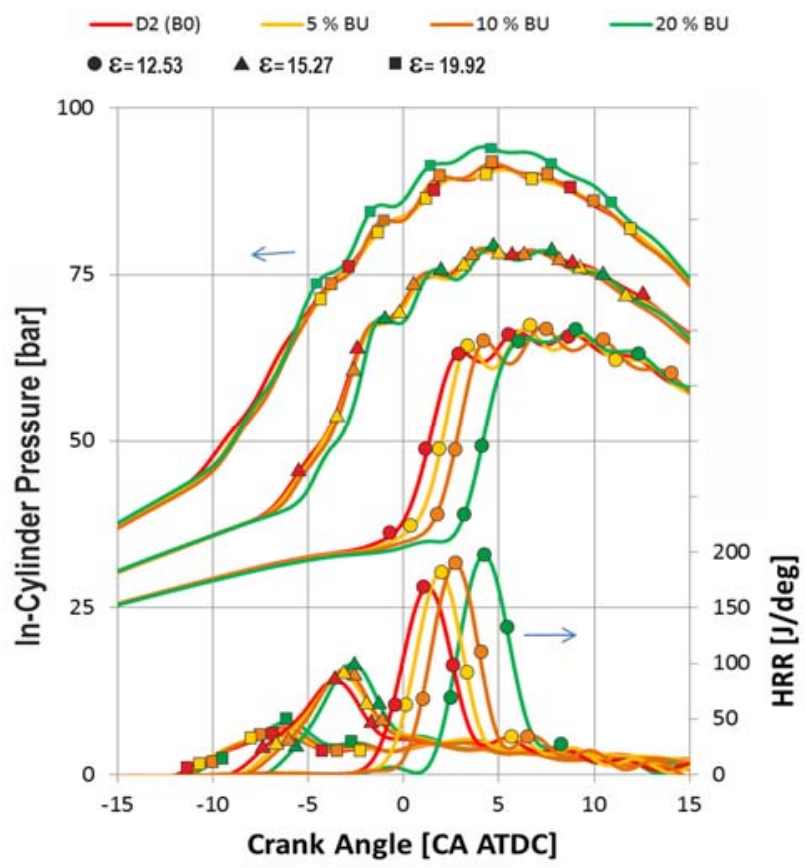

Figure 1. In-cylinder pressure and calculated HRR as a function of crankshaft angle with three different compression ratios $\left(\sigma_{\mathrm{Pi}} \pm 3.59 \%, \sigma_{\mathrm{HRR}} \pm 21.66 \%\right)$.
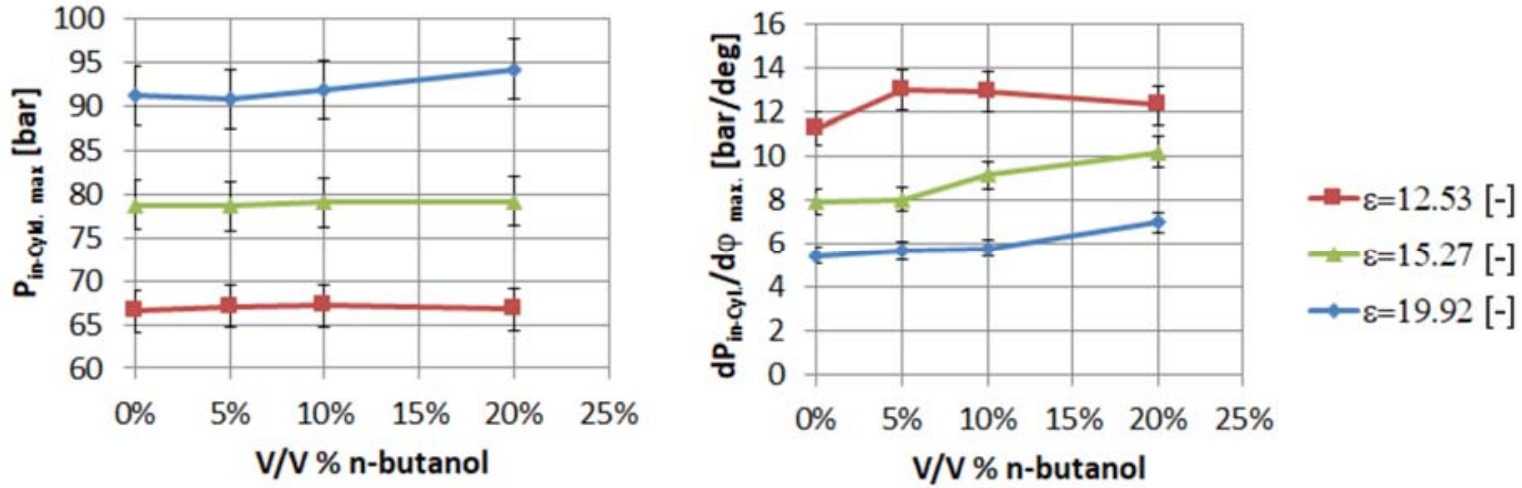

Figure 2. Maximal value of in-cylinder pressure and in-cylinder pressure changing rate over various blending rates with different compression ratios $\left(\sigma_{\mathrm{Pi}} \pm 3.59 \%\right)$.

Changes in maximal values of indicated pressure and pressure changing rate can be observed in Figures 2 and 3. Decreased compression ratio had a significant effect on the heat release's maximum value, which was a rising effect. The reason behind this is the intensity of the premixed combustion phase, which could last longer because of the longer ignition delay. 

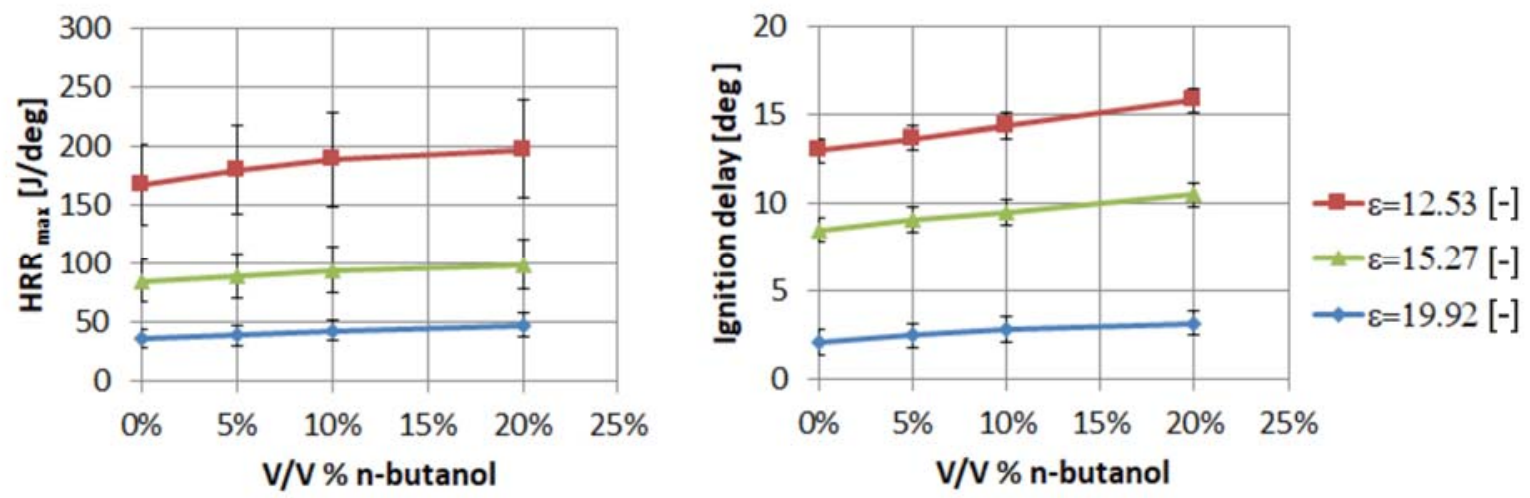

Figure 3. Change in maximum useful heat change (HRR) and Ignition delay to diesel ( $0 \mathrm{~V} / \mathrm{V} \% \mathrm{n}$-butanol) under different compression ratios and n-butanol ratios $\left(\sigma_{\mathrm{HRR}} \pm 21.66 \%\right)$.

Adding alcohol to the investigated blend also had an increased effect on the maximal value of the heat release that occurred in the premixed phase of the combustion. At $20 \mathrm{~V} / \mathrm{V} \%$ blending ratio of alcohol, the rate of growth reached $30 \%$ at the highest compression ratio (Figure 3). The ignition delay increases, which will indeed increase the intensity of the premixed combustion, but in the case of alcohol mixing, it is not the increase in the ignition delay that is primary, but the different evaporation of the alcohol. Based on Table 1, the boiling temperature is $390 \mathrm{~K}\left(117^{\circ} \mathrm{C}\right)$ for n-butanol and for diesel $453-643 \mathrm{~K}\left(180-370{ }^{\circ} \mathrm{C}\right)$. At a high compression ratio with low ignition delay, most of the alcohol evaporates and mixes, and when the diesel starts the combustion, the alcohol can burn well, so it will have a high HRR maximum. At low compression ratios, the ignition delay is relatively longer, the alcohol evaporates and the diesel as well, which means that the alcohol does not have a significant effect. The increase in ignition delay can be clearly explained by the significantly lower cetane number of n-butanol (Table 1) due to the higher heat of evaporation and the auto-ignition temperature.

Rising the compression ratio, i.e., with increasing the pressure and temperature parameters at the time of ignition, the ignition delay drops (Figure 3), and corresponding to the hypotheses, the ignition delay also rises as the alcohol ratio increased at a certain compression ratio set. In case the compression ratio was set at 19.92, the peak pressure seemed to be slightly increased due to the HRR increasing because of the increased alcohol ratio. In this case, the maximum of the useful heat change changed best with an increasing proportion of n-butanol (Figure 4), since the evaporation of n-butanol was initially significant. By reducing the compression ratio, the ignition time increased, so that not only n-butanol could leave the mixture, but also diesel. As a result, the effect of alcohol vapor was reduced. Furthermore, at a compression ratio of 12.53 , the ignition time was so long that the combustion occurred after the top dead center; thus, the higher premixed phase intensity increase could no longer compensate for the effect of expansion, and therefore, the rate of pressure increased and the value of peak pressure decreased with the mixing of alcohol. In Figure 4, it can be observed that in all three compression conditions, the maximum useful heat values is shifted vertically in positive direction with mixing of alcohol compared to the pure diesel operation. This is a continuously rising tendency, but the extent of values of increasing differs from each other depending on the compression ratio. In case of the two lower compression ratios figures are running together. A more extent in parameter's changing can be observed for the highest compression ratio, which reaches the $30 \%$ at $20 \mathrm{~V} / \mathrm{V} \%$ of $\mathrm{n}$ - butanol blending ratio. 


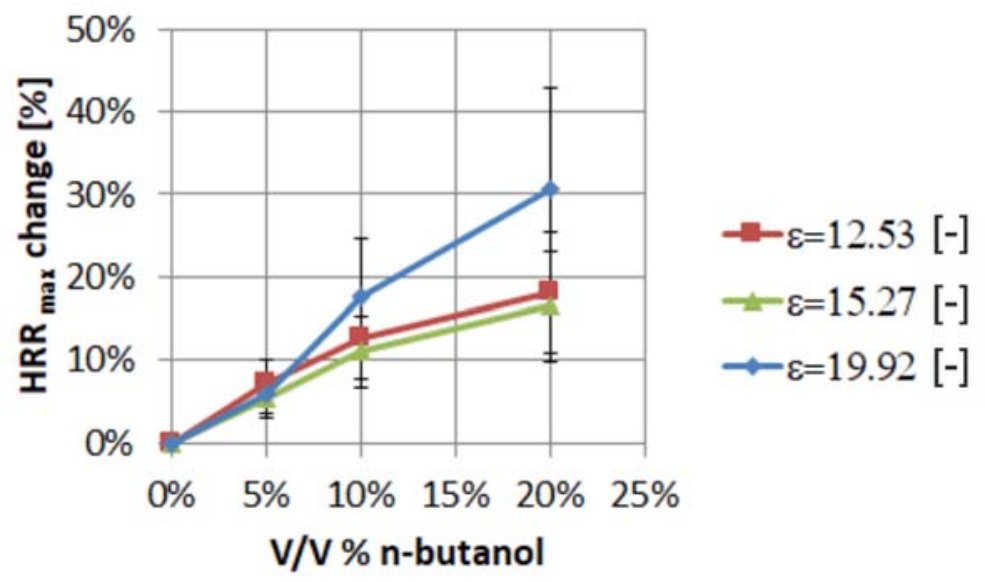

Figure 4. Change in maximum useful heat change (HRR) compared to diesel ( $0 \mathrm{~V} / \mathrm{V} \% \mathrm{n}$-butanol) under different compression ratios and n-butanol ratios.

\section{Conclusions}

Based on the above presented theoretical and experimental results the following conclusions can be outlined:

- In the case of the pre-chamber diesel engine when the fuel flow rate and pre-injection angle were constant, the ignition delay increased accordingly when the butanol ratio increased in the blend, but it was inversely proportional to the compression ratio. The maximal value of the heat release rate would be higher with increasing n-butanol in the fuel mixture, and it was also proportional to the increased compression ratio. Against the lowered LHV of the fuel, the blend contains n-butanol and the combustion peak pressure remained constant or a slightly increasing could be obtained.

- Additionally, with this engine with a constant flow rate of fuel and pre-injection angle, the ignition delay of blend with butanol increased most significantly with the highest compression ratio compared to that of diesel. It changed almost equally at lower compression ratios. Maximal values of heat release rate increased when a higher butanol part in the blend was investigated. This is the most intensive at a high compression ratio, while for the lower level of compression ratio, it changed almost equally. Clarification for that is that in case of a high compression ratio the ignition delay is lower than 2-3 $\mathrm{CA}^{\circ}$, so in this case, after the injection, a high quantity of butanol had evaporated, while only a small fraction of the diesel had done so. So, the mixture contained more n-butanol damp at the start of the combustion.

- When the compression ratios were lower, the ignition delay times were longer during which the butanol and also the diesel evaporated continuously. So at the start of the combustion, it appeared that the ratio of diesel to n-butanol was higher, as it was the situation in case of shorter ignition delays. It is supported by the above findings, so in the case of the used adjustments, the injection period was $5-6 \mathrm{CA}^{\circ}$, so it can be obtained that if the compression ratio was 12.53 , the period of the diffuse combustion process was not significantly in contrast to the process when the compression ratio was set to 19.92 .

Author Contributions: Conceptualization, Á.B.; methodology, Á.B. and K.L.; software, K.L.; validation, Á.B., K.L.; formal analysis, Á.B. and G.S.; investigation, K.L.; resources, Á.B., G.S.; writingoriginal draft preparation, Á.B. and G.S.; writing—review and editing, Á.B., G.S.; supervision, Á.B. All authors have read and agreed to the published version of the manuscript.

Funding: This research was funded by the National Research Development and Innovation Office under the auspices of the Ministry of Innovation and Technology. 
Acknowledgments: The research reported in this paper and carried out at the Budapest University of Technology and Economics has been supported by the National Research Development and Innovation Fund (TKP2020 National Challenges Subprogram, Grant No. BME-NCS) based on the charter of bolster issued by the National Research Development and Innovation Office under the auspices of the Ministry for Innovation and Technology.

Conflicts of Interest: The authors declare no conflict of interest.

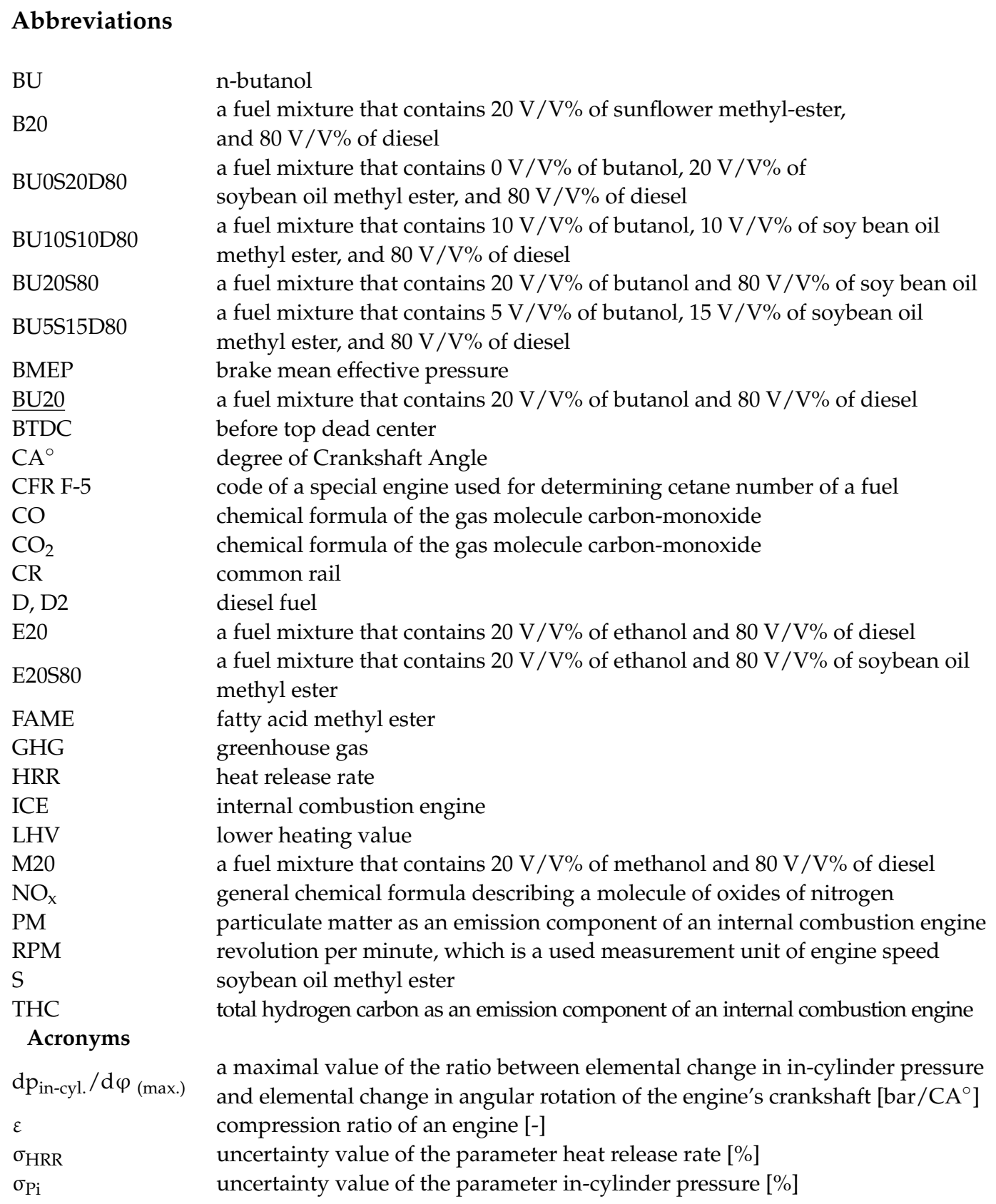

\section{References}

1. Liu, Y.; Cheng, W.L.; Huo, M.; Lee, C.F.; Li, J.; City, C.C.; Province, J.L.; Street, W.G. Effects of Micro-Explosion on ButanolBiodiesel-Diesel Spray and Combustion. In Proceedings of the ILASS-Americas 22nd Annual Conference on Liquid Atomization and Spray Systems, Cincinnati, OH, USA, May 2010; pp. 16-19. Available online: https://www.researchgate.net/profile/MingHuo-6/publication/228511913_Effects_of_Micro-Explosion_on_Butanol-Biodiesel-Diesel_Spray_and_Combustion/links/55 5c743508ae8f66f3ae352e/Effects-of-Micro-Explosion-on-Butanol-Biodiesel-Diesel-Spray-and-Combustion.pdf (accessed on 2 February 2021).

2. Lapuerta, M.; Hernández, J.J.; Fernández-Rodríguez, D.; Cova-Bonillo, A. Autoignition of blends of n-butanol and ethanol with diesel or biodiesel fuels in a constant-volume combustion chamber. Energy 2017, 118, 613-621. [CrossRef] 
3. Liu, H.; Lee, C.F.; Huo, M.; Yao, M. Comparison of ethanol and butanol as additives in soybean biodiesel using a constant volume combustion chamber. Energy Fuels 2011, 25, 1837-1846. [CrossRef]

4. Merola, S.S.; Tornatore, C.; Iannuzzi, S.E.; Marchitto, L.; Valentino, G. Combustion process investigation in a high speed diesel engine fuelled with n-butanol diesel blend by conventional methods and optical diagnostics. Renew. Energy 2014, 64, 225-237. [CrossRef]

5. Zhang, Z.H.; Balasubramanian, R. Influence of butanol-diesel blends on particulate emissions of a non-road diesel engine. Fuel 2014, 118, 130-136. [CrossRef]

6. Choi, B.; Jiang, X. Individual hydrocarbons and particulate matter emission from a turbocharged CRDI diesel engine fueled with n-butanol/diesel blends. Fuel 2015, 154, 188-195. [CrossRef]

7. Choi, B.; Jiang, X.; Kim, Y.K.; Jung, G.; Lee, C.; Choi, I.; Song, C.S. Effect of diesel fuel blend with n-butanol on the emission of a turbocharged common rail direct injection diesel engine. Appl. Energy 2015, 146, 20-28. [CrossRef]

8. Valentino, G.; Corcione, F.E.; Iannuzzi, S.E.; Serra, S. Experimental study on performance and emissions of a high speed diesel engine fuelled with n-butanol diesel blends under premixed low temperature combustion. Fuel 2012, 92, 295-307. [CrossRef]

9. Valentino, G.; Corcione, F.E.; Iannuzzi, S.E. Effects of gasoline-diesel and n-butanol-diesel blends on performance and emissions of an automotive direct-injection diesel engine. Int. J. Engine Res. 2012, 13, 199-215. [CrossRef]

10. Tornatore, C.; Marchitto, L.; Mazzei, A.; Valentino, G.; Corcione, F.E.; Merola, S.S. Effect of Butanol Blend on in-Cylinder Combustion Process. Part 2: Compression Ignition Engine. J. KONES 2011, 18, 473-483. Available online: http://yadda.icm.edu. pl/yadda/element/bwmeta1.element.baztech-article-BUJ5-0040-0059 (accessed on 3 February 2021).

11. Chen, G.; Shen, Y.; Zhang, Q.; Yao, M.; Zheng, Z.; Liu, H. Experimental study on combustion and emission characteristics of a diesel engine fueled with 2, 5-dimethylfuran-diesel, n-butanol-diesel and gasoline-diesel blends. Energy 2013, 54, 333-342. [CrossRef]

12. Lujaji, F.; Kristóf, L.; Bereczky, A.; Mbarawa, M. Experimental investigation of fuel properties, engine performance, combustion and emissions of blends containing croton oil, butanol, and diesel on a CI engine. Fuel 2011, 90, 505-510. [CrossRef]

13. Dobai, A.; Bereczky, Á. Investigation of Diesel-n-Butanol Fuel Blend in the Function of Pre-injection Angle. In Vehicle and Automotive Engineering; Jármai, K., Bolló, B., Eds.; Springer: Berlin/Heidelberg, Germany, 2018; pp. 3-13.

14. Economics, B.E. BP Energy Outlook 2018 Edition. 2018. Available online: https://www.bp.com/content/dam/bp/businesssites/en/global/corporate/pdfs/energy-economics/energy-outlook/bp-energy-outlook-2018.pdf (accessed on 2 May 2020).

15. Exxon Mobil. Outlook for Energy: A View to 2040. 2018. Available online: Cdn.exxonmobil.com/ \{\}/media/global/files/ outlook-for-energy/2018/2018-outlook-for-energy.pdf (accessed on 2 May 2020).

16. Shell. Shell Energy Transition Report. 2017. Available online: https://www.shell.com/energy-and-innovation/the-energyfuture/shell-energy-transition-report/_jcr_content/par/toptasks.stream/1524757699226/f51e17dbe7de5b0eddac2ce19275dc9 46db0e407ae60451e74acc7c4c0acdbf1/web-shell-energy-transition-report.pdf (accessed on 2 May 2020).

17. Shell International BV. Shell Energy Scenarios to 2050. 2016. Available online: https://rjohnwilliams.files.wordpress.com/2016/0 2/shell-energy-scenarios2050.pdf (accessed on 2 May 2020).

18. Fischer, G.; Schrattenholzer, L. Global bioenergy potentials through 2050. Biomass Bioenergy 2001, 20, 151-159. [CrossRef]

19. Zöldy, M. Potential future renewable fuel challenges for internal combustion engine. Jármûvek és Mobilgépek II. évf 2009, 397-403.

20. Ricardo. Europe's Clean Mobility Outlook: Scenarios for the EU Light-Duty Vehicle Fleet, Associated Energy Needs and Emissions, 2020-2050. 2018. Available online: https://www.epure.org/media/1751/ed51122_epure_cmp_modelling_finalreport_issue3-1.pdf (accessed on 2 May 2020).

21. Hancsók, J.; Krár, M.; Baladincz, J.; Vuk, T. Dízelgázolajok bioeredetú komponensei (Zsírsav-metilészterek) (Bio-origin components of diesel (Fatty acid methyl esters)). Magy. Kémikusok Lapja 2006, 61, 228-235. (In Hungarian)

22. Hancsók, J.; Magyar, S.; Szoboszlai, Z. Motorbenzinek bioeredetû́ komponensei I. (Bioalkoholok) (Bio-origin components of gasoline I. (Bioalcohols)). Magy. Kémikusok Lapja 2006, 61, 153-159. (In Hungarian)

23. European Parliament and Council. Directive 2009/28/EC of the European Parliament and of the Council of 23 April 2009 on the Promotion of the Use of Energy from Renewable Sources and Amending and Subsequently Repealing Directives 2001/77/EC and 2003/30/EC; European Parliament and Council: Strasbourg, France, 2009.

24. Mączyńska, J.; Krzywonos, M.; Kupczyk, A.; Tucki, K.; Sikora, M.; Pińkowska, H.; Wielewska, I. Production and use of biofuels for transport in Poland and Brazil-The case of bioethanol. Fuel 2019, 241, 989-996. [CrossRef]

25. Mollenhauer, K.; Tschoke, H. Handbook of Diesel Engines; Springer: Berlin, Germany, 2010; Volume 1.

26. Hartmann Braun Meß und Regeltechik Verbrennungstechnik; Hartmann Braun AG: Frankfurt, Germany, 1973.

27. Herbinet, O.; Pitz, W.J.; Westbrook, C.K. Detailed chemical kinetic mechanism for the oxidation of biodiesel fuels blend surrogate. Combust. Flame 2010, 157, 893-908. [CrossRef]

28. Westbrook, C.K.; Naik, C.V.; Herbinet, O.; Pitz, W.J.; Mehl, M.; Sarathy, S.M.; Curran, H.J. Detailed chemical kinetic reaction mechanisms for soy and rapeseed biodiesel fuels. Combust. Flame 2011, 158, 742-755. [CrossRef]

29. Heywood, J.B. Combustion Engine Fundamentals, 1st ed.; McGraw-Hill, Inc.: New York, NY, USA, 1988.

30. European Committee for Standardization. European Standard EN 590 Automotive Fuels. Diesel. Requirements and Test Methods; CEN-European Committee for Standardization: Brussels, Belgium, 2005.

31. Rakopoulos, D.C.; Rakopoulos, C.D.; Giakoumis, E.G.; Dimaratos, A.M.; Kyritsis, D.C. Effects of butanol-diesel fuel blends on the performance and emissions of a high-speed DI diesel engine. Energy Convers. Manag. 2010, 51, 1989-1997. [CrossRef] 
32. Horváth, I.T.; Cséfalvay, E.; Mika, L.T.; Debreczeni, M. Sustainability metrics for biomass-based carbon chemicals. ACS Sustain. Chem. Eng. 2017, 5, 2734-2740. [CrossRef]

33. Ndaba, B.; Chiyanzu, I.; Marx, S. n-Butanol derived from biochemical and chemical routes: A review. Biotechnol. Rep. 2015, 8, 1-9. [CrossRef] [PubMed]

34. Babu, V.; Murthy, M. Butanol and pentanol: The promising biofuels for CI engines-A review. Renew. Sustain. Energy Rev. 2017, 78, 1068-1088.

35. Kumar, B.R.; Saravanan, S. Use of higher alcohol biofuels in diesel engines: A review. Renew. Sustain. Energy Rev. 2016, 60, 84-115. [CrossRef]

36. Davis, S.G.; Law, C.K. Determination of and fuel structure effects on laminar flame speeds of C1 to C8 hydrocarbons. Combust. Sci. Technol. 1998, 140, 427-449. [CrossRef] 